\title{
PENGARUH PEMBELAJARAN MIND MAPPING BERMEDIAKAN RUMAH BELAJAR JEJAK BALI TERHADAP HASIL BELAJAR SISWA PADA MATA PELAJARAN ANATOMI FISIOLOGI DI SMK NEGERI 1 KUBUTAMBAHAN (SMK KESEHATAN)
}

\author{
Komang Agus Satia Darma ${ }^{1}$, Ketut Agustini², Gede Aditra Pradnyana ${ }^{3}$ \\ Program Studi Pendidikan Teknik Informatika \\ Jurusan Teknik Informatika \\ Fakultas Teknik dan Kejuruan \\ Universitas Pendidikan Ganesha \\ e-mail : $\underline{\text { satyadharma997@gmail.com }}{ }^{1}, \underline{\text { ketutagustini@ undiksha.ac.id }}{ }^{2}$, gede.aditra@ undiksha.ac.id $^{3}$
}

\begin{abstract}
Abstrak- Penelitian bertujuan untuk mengetahui (1) mengetahui apakah terdapat perbedaan hasil belajar siswa yang belajar menggunakan pembelajaran mind mapping bermediakan rumah belajar jejak bali dengan siswa yang belajar menggunakan model pembelajaran discovery elearning dengan bermediakan powerpoint pada mata pelajaran anatomi fisiologi siswa kelas $\mathrm{X}$ Jurusan keperawatan SMK Negeri 1 Kubutambahan (2) mengetahui respon siswa setelah belajar menggunakan pembelajaran mind mapping bermediakan rumah belajar jejak bali mata pelajaran Anatomi Fisiologi.

Jenis penelitian ini adalah eksperimen semu dengan desain Post Test Only Group Control Design. Populasi penelitian mencakup seluruh siswa kelas $\mathrm{X}$ jurusan keperawatan SMK Negeri 1 Kubutambahan tahun pelajaran 2018/2019. Metode pengumpulan data yang digunakan yaitu metode tes uraian untuk mengukur hasil belajar, dan metode angket untuk menganalisis respon siswa. Data hasil belajar kemudian dianalisis dengan melakukan uji prasyarat yang meliputi uji normalitas, uji homogenitas dan uji- t.

Hasil penelitian menunjukkan (1) bahwa terdapat hasil belajar yang lebih tinggi antara siswa yang belajar menggunakan pembelajaran mind mapping bermediakan rumah belajar jejak bali dengan siswa yang belajar menggunakan pembelajaran discovery learning bermediakan powerpoint pada mata pelajaran anatomi fisiologi siswa kelas $\mathrm{X}$ jurusan keperawatan di SMK Negeri 1 Kubutambahan. Hasil analisis uji-t memperoleh $t_{\text {hitung }}$ sebesar 20,316 dan $t_{\text {tabel }}$ sebesar 2,0024 untuk dk sebesar 57 dengan taraf signifikan 5\%. Berdasarkan kriteria pengujian diperoleh $\mathrm{t}_{\text {hitung }}>\mathrm{t}_{\text {tabel }}$, ini berarti $\mathrm{H}_{0}$ ditolak. (2) respon siswa setelah menggunakan pembelajaran mind mapping bermediakan rumah belajar jejak bali pada mata anatomi fisiologi adalah sangat positif dilihat dari rata-rata skor hasil angket respon siswa yaitu 112,47.
\end{abstract}

Kata Kunci : Mind Mapping, Rumah Belajar Jejak Bali, Anatomi Fisiologi.

\begin{abstract}
This study aims to (1) find out whether are differences in student learning outcomes wtich learn to use mind mapping learning, frovide a learning house, troces of bali with students learning using discovery learning learning models by providing power point on anatomy physiology subjects in grade $x$ senior vocational school nursing 1 ladded (2) to find out the response of students after learning to use mind mapping learning to provides a home to learn the traces of bali anatomy physiologi subjects.
\end{abstract}

This type of research is a quasi-experimental design with past test only group control design. The study population included all class $X$ students on the senior vocational school mursing 1 added the academic year 2018/2019. Data collection methods used are the description mettiond for measuring learning outcomes, and the questionnaire method for analyzing student responses.learning outcomes data were then analyzed by conducting prerequisite tests which included normality tests, homogeneity test and $t$-tests.

The results of the study show (1) that the higher learning outcomes between students who learn using mind mapping provides a learning house for Bali tracks with students learning to use discovery learning to provide power points on anatomy physiology subjects in class $X$ nursing mojors in public senior vocational schools 1 added the results of the t-test analysis obtained $t_{\text {count }}$ of 20,316 and table of 2,0024 for dk of 57 with a signiticant level of 5\%. Based on the testing criteria obtained

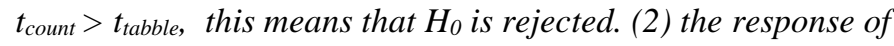
students after using mind mapping learning to provide a learning house for the Bali trail on subjects is very positive seen from the average score of the student response questionnaire which is 112,47 .

Keywords: Mind Mapping, House Learning Trace Of Bali, Anatomy Physiology 


\section{ISSN 2252-9063 \\ Kumpulan Artikel Mahasiswa Pendidikan Teknik Informatika \\ (KARMAPATI)

\section{PENDAHULUAN}

Belajar merupakan aktivitas manusia yang penting dan tidak dapat dipisahkan dari kehidupan manusia, bahkan sejak mereka lahir sampai akhir hayat. Pernyataan tersebut menjadi ungkapan bahwa manusia tidak dapat lepas dari proses belajar itu sendiri sampai kapanpun dan dimanapun manusia berada dan belajar juga menjadi kebutuhan yang terus meningkat sesuai dengan perkembangan ilmu pengetahuan [1]

SMK (Sekolah Menengah Kejuruan) adalah sekolah formal yang dibentuk dalam menyelenggarakan pendidikan kejuruan yang setara dengan sekolah menengah. SMK (Sekolah Menengah Kejuruan) terfokus kepada mencetak siswasiswinya agar siap untuk terjun kedunia kerja, sehinnga mata pelajaran yang ditempuh hampir keseluruhan terfokus pada keahlian yang dibutuhkan didunia kerja sesuai dengan masingmasing jurusan yang diambil. Salah satu SMK yang ada di Bali khususnya di Singaraja yaitu SMK Negeri 1 Kubutambahan dengan jurusan keperawatan. Sekolah ini menuntut siswasiswinya untuk menguasai dalam bidang ilmu keperawatan termasuk mata pelajaran Anatomi Fisiologi.

Berdasarkan wawancara dilakukan oleh guru produktif bidang keperawatan di SMK 1 Kubutambahan, untuk kelas X khususnya di mata pembelajaran Anatomi fisiologi siswa memperoleh hasil dibawah KKM 75, dikelas X siswa yang berjumlah 117 siswa yang dibagi bedasarkan 4 kelas yaitu satu tahun kebelakang perolehan ulangan dengan nilai rata-rata sebesar 49,99 dengan presentase di bawah KKM berjumlah $100 \%$. Hal ini membuktikan bahwa tidak ada satupun siswa yang nilainya berada diatas KKM dalam hal mata pembelajaran Anatomi Fisiologi

Rendahnya hasil belajar ini dikarenakan pada umumnya didalam proses pembelajaran dikelas guru hanya menerapkan model dan media yang sama terus menerus pada proses kegiatan pembelajaran belangsung dikelas, hal ini dilihat dari hasil observasi awal didalam kelas peneliti menemukan bahwa kegiatan pembelajaran dikelas guru masih menggunakan model discovery learning.

Hal penting selama observasi awal didalam kelas peneliti menemukan yakni didalam kegiatan proses pembelajaran belangsung guru belum menerapkan media pembelajaran berbasis e-learning didalam proses penyampaian materi dikelas, hanya saja guru sudah menggunakan media pembelajaran powerpoint. Dilihat didalam observasi peneliti menemukan siswa didalam proses pembelajaran yaitu siswa cepat bosan didalam proses pembelajaran dan kurangnya partisipasi aktif dari siswa dalam merespon pertanyaan dari guru. Salah satu upaya yang dapat dilakukan agar siswa teribat aktif dalam proses pembelajaran yakni dengan model pembelajaran yang sesuai dengan materi yang diajarkan. Salah satunya dengan menggunakan model pembelajaran mind mapping dengan bermediakan e-learning rumah belajar jejak bali. Peranan model mind mapping sangat penting pada mata pelajaran Antomi Fisiololgi, karena dalam mata pelajaran Anatomi Fisiologi membuat beberapa konsep yang saling terkait dan merupakan hubungan sebab akibat. Peta pikiran yang dibuat dapat membantu siswa dalam proses belajar mengajar. Tanda atau simbol-simbol yang digunakan serta warna sangat mempengaruhi dalam penguatan pemahaman dan memori [2].

Menurut Buzan dalam [3] mind mapping (peta pikiran) dapat diartikan sebagai suatu cara untuk mengorganisasikan dan menyajikan konsep, ide, tugas, atau informasi lainnya dalam bentuk diagram visual. Dengan pembelajaran mind mapping ini dapat memudahkan siswa memahami suatu konsep atau materi secara bertahap, pembelajaran ini juga menyenangkan dikarenakan siswa lebih kreatif membuat materinya sendiri, hal ini akan memperkuat daya ingat siswa dan dapat memudahkan siswa untuk meriview apa yang telah dipelajari..

Sedangkan media pembelajaran berbasis e-learning yaitu Pemerintah Indonesia sudah memiliki Undang-Undang No.20 Tahun 2003 tentang Sistem Pendidikan Nasional pasal 31 dan SK Mendiknas No. 107/U/2001 tentang Pendidikan Tinggi Jarak Jauh (PTJJ). UU ini mengijinkan penyelenggara pendidikan di Indonesia untuk melaksanakan pendidikan melalui cara PTJJ dengan memanfaatkan Teknologi Informasi, yang mengakomodasi e-learning. Kebijakan e-learning tersebut akan terangkum dalam cetak biru peranan Teknologi Informasi dan Komunikasi dalam Tatanan Sistem Pendidikan Dasar dan Menengah [4].

Pemerintah sudah menyediakan sebuah fasilitas $e$ learning yang disebut Rumah Belajar Jejak Bali untuk tingkat pendidikan dijenjang bangku SD, SMP, dan SMA/SMK, yang dapat diakses dengan mudah oleh semua siswa dan guru dari seluruh Indonesia melalui jejaring yang terhubung melalui internet. Rumah belajar jejak bali merupakan media pembelajaran resmi Kementerian Pendidikan dan Kebudayaan, dengan alamat url https://belajar.kemdikbud.go.id/jejakbali, rumah belajar jejak bali menyediakan berbagai bahan belajar serta fasilitas komunikasi dan interaksi antar komunitas pendidikan. Rumah belajar jejak bali ini berisi bahan belajar untuk guru, bahan belajar siswa, wahana aktivitas komunitas/forum, bank soal dan katalog media pembelajaran.

Berdasarkan uraian tersebut, maka penulis tertarik untuk menerapkan model pembelajaran mind mapping berbantuan media pembelajaran e-learning rumah belajar jejak bali pada mata pelajaran anatomi fisiologi pada siswa kelas X di SMK Negeri 1 Kubutambahan. Penelitian yang dilakukan adalah penelitian eksperimental semu (quasi) dengan pola dasar Post Test Only Control Group Design. Dalam penelitian yang berjudul "Pengaruh Pembelajaran Mind Mapping Bermediakan Rumah Belajar Jejak Bali Terhadap Hasil Belajar Siswa Pada Mata Pelajaran Anatomi Fisiologi Di SMK Negeri 1 Kubutambahan (SMK KESEHATAN)". 
ISSN 2252-9063

Kumpulan Artikel Mahasiswa Pendidikan Teknik Informatika

(KARMAPATI)

Volume 8, Nomor 2, Tahun 2019

\section{KAJIAN TEORI}

\section{A. Teori Belajar}

Belajar adalah suatu proses usaha yang dilakukan seseorang untuk memperoleh suatu perubahan tingkah laku yang baru secara keseluruhan, sebagai hasil pengalamannya sendiri dalam interaksi dengan lingkungannya. Pengertian ini senada dengan pengertian belajar yang dikemukakan oleh Gagne dalam [5] juga menyatakan bahwa belajar adalah suatu perubahan dalam kemampuan yang bertahan lama dan bukan berasal dari proses pertumbuhan. Ada empat kategori utama atau kerangka filosofis mengenai teori-teori belajar, yaitu: teori belajar behaviorisme, teori belajar kognitivisme, teori belajar konstruktivisme dan teori belajar Connectivism.

Teori belajar behaviorisme adalah perubahan tingkah laku sebagai akibat dari adanya interaksi antara stimulus dan respon [6]. Dengan kata lain, belajar merupakan bentuk perubahan yang dialami siswa dalam hal kemampuannya untuk bertingkah laku dengan cara yang baru sebagai hasil interaksi antara stimulus dan respon.

Teori belajar kognitivisme merupakan suatu proses internal yang mencakup ingatan, retensi, pengolahan informasi, emosi, dan aspek-aspek kejiwaan lainnya. Oleh karena itu, teori kognitivisme lebih mementingkan proses belajar dari pada hasil belajar itu sendiri.

Teori belajar konstruktivisme yaitu teori yang lebih diarahkan pada terbentuknya makna pada diri pemelajar atas apa yang dipelajarinya bedasarkan pengetahuan dan pemahaman mereka sebelumnya. Dalam proses ini lebih ditekankan pada terbentuknya hubungan-hubungan makna antara pengetahuan yang telah ada dan pengetahuan baru dengan fasilitasi kreativitas guru selaku mediator pembelajaran [6].

Teori connectivism diperkenalkan George Siemen. Connectivism merupakan teori pembelajaran yang digunakan untuk era digital masa kini dan merupakan alternatif teori pembelajaran pada abad digital. Teori connectivism dinilai dapat membentuk siswa agar mampu berpikir lebih kritis dalam menerima informasi-informasi yang didapatkan di dalam belajar.

\section{B. Model Pembelajaran}

Model pembelajaran merupakan sebuah rencana atau terpola yang dapat digunakan untuk menentukan kurikulum (rencana pembelajaran jangka panjang), merancang bahan pembelajaran, dan membingbing pembelajaran di kelas atau lainnya. Menurut Arends dalam [6] menjelaskan bahwa model pembelajaran adalah suatu perencanaan atau suatu pola yang digunakan sebagai pedoman dalam merencanakan suatu pembelajaran di dalam kelas.

\section{Model Pembelajaran Mind Mapping}

Didalam beberapa model pembelajaran yang ada, salah satu model yang telah mampu mengotimalkan hasil belajar adalah model peta pikiran atau disebut mind mapping. Pembelajaran ini pertama kali diperkenalkan oleh Buzan pada awal 1970-an yaitu seorang ahli dan penulis produktif di bidang psikologi dari inggris. Beliau adalah penemu mind mapping (peta pikiran). Mind mapping diaplikasikan di bidang pendidikan, seperti teknik, sekolah, artikel, serta menghadapi ujian.Menurut Silberman dalam [7] mind mapping atau pemetaan pikiran merupakan cara kreatif bagi tiap siswa untuk menghasilkan gagasan, mencatat apa yang di pelajari atau merencanakan tugas baru. Dalam arti lain model pembelajaran mind mapping merupakan model pembelajaran yang dapat mengembangkan kreatifitas, keaktifan, daya hafal, pengetahuan dan kemandirian siswa dalam mencapai tujuan pembelajar.

Peta pikiran adalah teknik pemanfaatan seluruh otak dengan menggunakan citra visual dan prasarana grafis lainnya untuk membentuk kesan. Pembelajaran ini sangat cocok untuk mereview pengetahuan awal siswa. Daya pikir peserta didik sering kali mengingat informasi dalam bentuk gambar, simbol, suara bentuk-bentuk, dan perasaan. Menurut [7] pembelajaran mind mapping memiliki beberapa kelebihan dan kekurangan diantaranya :

1) Cara ini cepat dalam menyelesaikan permasalahan

2) Teknik dapat digunakan untuk mengorganisasikan ideide yang muncul dalam pemikiran.

3) Proses menggambar diagram bisa memunculkan ide-ide yang lain.

Sedangkan kekurangan dari model mind mapping diantaranya :

1) Hanya siswa yang aktif yang terlibat

2) Tidak sepenuhnya murid yang belajar

3) Mind mapping siswa bervariasi sehingga guru akan kewalahan memeriksa mind mapping

\section{Media Pembelajaran}

Kata media berhasal dari bahasa latin "medius", yang secara harfian berarti "tengah" atau "pengantar". Pengertian umumnya adalah segala sesuatu yang dapat menyalurkan informasi dari sumber informasi kepada penerima informasi [8]. Menurut Gagne dalam [8] mengartikan media sebagai berbagai jenis komponen dalam lingkungan siswa yang dapat merangsang siswa untuk belajar. Media pembelajaran adalah media yang digunakan dalam pembelajaran, yaitu meliputi alat bantu guru dalam mengajar serta sarana pembawa pesan dari sumber belajar ke penerima pesan belajar (siswa). Salah satu teori yang paling banyak dijadikan acuan sebagai landasan teori penggunaan media dalam proses pembelajaran adalah Dale's Cone of Experience (Kerucut pengalaman Dale). Berikut adalah gambaran kerucut pengalaman Dale : 
ISSN 2252-9063

Kumpulan Artikel Mahasiswa Pendidikan Teknik Informatika

(KARMAPATI)

Volume 8, Nomor 2, Tahun 2019

\section{Dale's Cone of Experience}

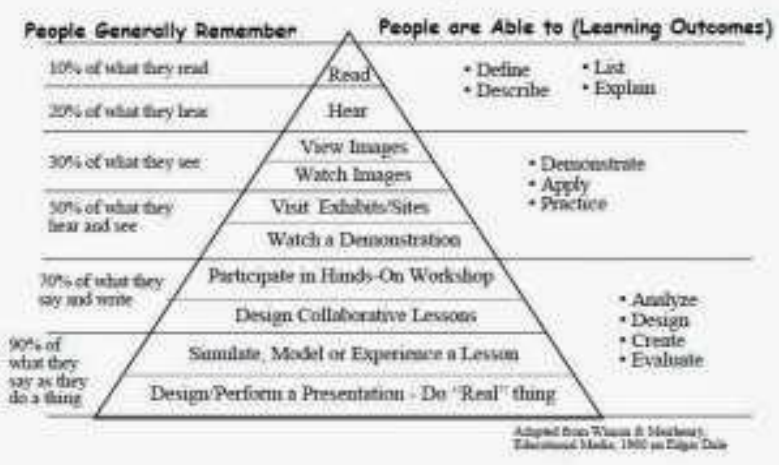

Gambar 1. Kerucut Pengalaman Dale

Sumber : (Arsyad, 2013, h.10).

\section{E. Media E-learning Rumah Belajar Jejak Bali}

E-learning mengandung pengertian yang sangat luas, sehingga banyak pakar yang menguraikan tentang definisi $e$ learning dari berbagai sudut pandang. Salah satunya menurut Ratnasari dalam [9] menyimpulkan bahwa yang disebut sebagai e-learning adalah konsep pendidikan yang memanfaatkan teknologi informasi dan komunikasi dalam proses belajar mengajar. Salah satu dari media pembelajaran yang berbasis $e$ learning yaitu media pembelajaran rumah belajar jejak bali yang sudah disiapkan oleh Dinas Provinsi Bali. Media pembelajaran e-learning rumah belajar jejak bali menawarkan solusi di dalam perannya sebagai teknologi baru, diantaranya :

1) Rumah belajar jejak bali menyediakan bank Soal.

2) Rumah belajar jejak bali menyediakan fasilitas forum diskusi.

3) Rumah belajar jejak bali menyediakan modul (bahan ajar) dan LSM (learning management system) yang dapat memfasilitasi siswa yang ingin belajar secara mandiri.

\section{F. Hasil Belajar}

Tujuan utama yang ingin dicapai dalam kegiatan pembelajaran adalah hasil belajar. Hasil belajar dapat ditingkatkan melalui usaha sadar yang dilakukan secara sistematis mengarah pada perubahan yang positif yang kemudian disebut dengan proses belajar. Bukti bahwa seseorang telah belajar adalah adanya perubahan tingkah laku dari seseorang tersebut yang dapat diamati dan diukur dalam bentuk pengetahuan misalnya dari tidak tahu menjadi tahu, dari tidak mengerti menjadi mengerti [6]. Perubahan tersebut dapat diartikan terjadinya peningkatan dan pengembangan yang lebih baik dibandingkan dengan sebelumnya. Hasil belajar digunakan untuk mengetahui sebatas mana siswa dapat memahami serta mengerti materi tersebut. Dengan hasil belajar guru dapat mengetahui kemampuan peserta didiknya.

\section{METODOLOGI PENELITIAN}

\section{A. Jenis Penelitian}

Desain penelitian yang digunakan adalah Post Test Only Group Control Design dengan jenis penelitian yang digunakan dalam penelitian ini adalah penelitian eksperimen semu. Dikatakan sebagai eksperimen semu karena tidak semua variabel dan kondisi eksperimen dapat diatur dan kontrol secara ketat. Pada penelitian ini diberikan perlakuan yang berbeda antara ke dua kelas sampel yang digunakan. Kelas pertama sebagai kelas eksperimen akan diberikan perlakuan berupa pembelajaran mind mapping bermediakan rumah belajar jejak bali dalam mata pelajaran Anatomi Fisiologi, sedangkan kelas kedua sebagai kelas kontrol akan diberikan perlakuan berupa penggunaan pembelajaran discovery learning bermediakan powerpoint dalam mata pelajaran Anatomi fisiologi.

\section{B. Tempat Dan Waktu Penelitian}

Penelitian ini dilaksanakan di SMK Negeri 1 kubutambahan kelas X Jurusan Keperawatan. Waktu pelaksanaan penelitian ini adalah rentangan waktu semester genap pada tahun ajaran $2018 / 2019$.

\section{Populasi Dan Sampel Penelitian}

\section{1) Populasi}

Populasi adalah wilayah generalisasi yang terdiri atas objek/subyek yang mempunyai kualitas dan karakteristik tertentu yang ditetapkan oleh peneliti untuk dipelajari dan kemudian ditarik kesimpulannya. Populasi dalam penelitian ini adalah kelas $\mathrm{X}$ jurusan keperawatan semester genap SMK Negeri 1 Kubutambahan tahun ajaran 2018/2019. Distribusi jumlah siswa kelas X jurusan keperawatan di SMK Negeri 1 Kubutambahan pada tahun 2018/2019 disajikan pada Tabel 1.

Tabel 1 Populasi Penelitian

\begin{tabular}{|c|c|c|}
\hline No & Kelas & Jumlah Siswa \\
\hline 1 & X KP 1 & 30 \\
\hline 2 & X KP 2 & 30 \\
\hline 3 & X KP 3 & 29 \\
\hline 4 & X KP 4 & 28 \\
\hline \multicolumn{2}{|c|}{ Jumlah } & 117 \\
\hline
\end{tabular}

\section{2) Sample Penelitian}

Sampel adalah sebagian kecil dari jumlah dan karakteristik yang dimiliki oleh populasi. Teknik pengambilan sampel dalam penelitian ini yaitu dengan cara random sampling, dan yang di random adalah kelas. Cara ini dipilih karena sulit mengubah kelas yang sudah terbentuk. Kelas dipilih sebagaimana telah terbentuk tanpa campur tangan peneliti sehingga kemungkinan pengaruh dari keadaan subjek mengetahui dirinya dilibatkan dalam eksperimen dapat dikurangi sehingga penelitian ini 
ISSN 2252-9063

Kumpulan Artikel Mahasiswa Pendidikan Teknik Informatika

(KARMAPATI)

benar-benar menggambarkan pengaruh perlakuan yang diberikan. Berdasarkan hasil pengundian dengan teknik simple random sampling maka ditetapkan kelas X KP 1 sebagai kelompok eksperimen dan kelas KP 3 sebagai kelas kelompok kontrol. Perbandingan kelas eksperimen dan kontrol dapat dilihat pada Tabel 2 .

Tabel 2. Sampel Penelitian

\begin{tabular}{|l|c|c|}
\hline \multicolumn{1}{|c|}{ Kelompok } & Kelas & Jumlah Siswa \\
\hline Kontrol & X KP 3 & 29 \\
\hline Eksperimen & X KP 1 & 30 \\
\hline \multicolumn{2}{|c|}{ Jumlah } & 59 \\
\hline
\end{tabular}

D. Variabel Penelitian

Variabel penelitian adalah suatu atribut atau sifat atau nilai dari orang, obyek atau kegiatan yang mempunyai variasi tertentu yang ditetapkan oleh peneliti untuk dipelajari dan kemudian ditarik kesimpulannya Dalam penelitian ini terdapat dua variabel yaitu variabel bebas.

\section{1) Variabel Bebas}

Variabel bebas (independent variable) merupakan variabel yang mempengaruhi variabel lain atau menghasilkan akibat pada variabel yang lain, yang pada umumnya berada dalam urutan tata waktu yang terjadi lebih dulu [10]. Variabel bebas dalam penelitian ini adalah media pembelajaran yang akan diteliti yaitu pembelajaran mind mapping bermediakan rumah belajar jejak bali.

\section{2) Variabel Terkait}

Variabel terikat (dependent variable) merupakan variabel yang diakibatkan atau dipengaruhi oleh variabel bebas. Keberadaan variabel dalam penelitian kuantitatif adalah sebagai variabel yang dijelaskan dalam fokus atau topic penelitian. Variabel terikat yang dalam penelitian ini adalah hasil belajar kelas X jurusan keperawatan pada mata pelajaran amatomi fisiologi di SMK Negeri 1 Kubutambahan. Hubungan antar variabel yang akan digunakan pada penelitian ini dapat dilihat pada Gambar 1.

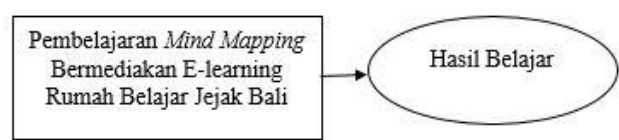

Gambar 2. Diagram Hubungan Variabel

\section{E. Uji Coba Instrumen Penelitian}

Sebelum digunakan, instrumen penelitian pada ranah kognitif diuji terlebih dahulu apakah tes hasil belajar sudah layak digunakan sebagai instrumen penelitian. Instrumen dikatakan sesuai jika instrumen tersebut sudah memenuhi kriteria Validitas, Reliabilitas. Kualitas item, khususnya di representasi oleh Indeks Kesukaran Butir (IKB), Indeks Daya beda Butir (IDB). Untuk memperoleh tujuan dari proses analisis, data terlebih dahulu dianalisis dengan menggunakan uji validitas tes dan reliabilitas tes.

\section{1) Uji Validitas Isi}

Validitas isi menunjukkan sejauh mana pertanyaan, tugas atau butir dalam suatu tes atau instrumen mampu mewakili secara keseluruhan dan proporsional keseluruhan perilaku sampel yang menjadi tujuan pembelajaran yang akan diukur pencapainnya. Untuk mengetahui apakah tes itu valid atau tidak, harus dilakukan melalui penelaahan kisi-kisi tes untuk memastikan bahwa soal-soal tes itu sudah mewakili atau mencerminkan keseluruhan konten atau materi yang seharusnya dikuasai secara proporsional.

\section{2) Uji Reliabilitas}

Pengujian relibilitas pada penelitian ini menggunakan formula Alpha Cronbach seperti pada rumus dibawah ini [11]:

$$
\mathrm{r}_{11}=\left(\frac{\mathrm{k}}{k-1}\right)\left(1-\frac{\Sigma \sigma_{\mathrm{b}^{2}}}{\Sigma \sigma_{\mathrm{t}^{2}}}\right)
$$

Keterangan :

$\begin{array}{ll}\mathrm{r}_{11} & =\text { Reliabilitas instrumen } \\ \mathrm{K} & =\text { Banyaknya butir pertanyaan } \\ \Sigma \sigma_{\mathrm{b}}^{2} & =\text { Jumlah varians butir } \\ \Sigma \sigma_{\mathrm{t}}{ }^{2} & =\text { Varian total }\end{array}$

Kriteria yang digunakan dalam uji reliabilitas ini adalah mengikuti pendapat Guilfrod yang terlihat pada tabel 3 dibawah ini :

Tabel 3. Tingkat Reliabilitas Rumus Alpha Cronbach

\begin{tabular}{|c|c|}
\hline Rentangan Skor & Kategori \\
\hline $\mathrm{r} 11 \leq 0,20$ & Sangat Rendah \\
\hline $0,20 \leq \mathrm{r} 11<0,40$ & Rendah \\
\hline $0,40 \leq \mathrm{r} 11<0,60$ & Sedang \\
\hline $0,60 \leq \mathrm{r} 11<0,80$ & Tinggi \\
\hline $0,80<\mathrm{r} 11<1,00$ & Sangat Tinggi \\
\hline
\end{tabular}

\section{3) Uji Indeks Kesukaran Butir}

Instrument yang diuji coba merupakan tes berbentuk uraian (non dikotomi). Oleh karena itu, validitas dan reliabilitas tes diketahui harus dilanjutkan dengan uji taraf (indeks) kesukaran butir. Umumnya uji taraf kesukaran butir dilakukan dengan memperhitungkan banyak responden yang menjawab butir tersebut dengan benar. Rumus yang digunakan adalah sebagai berikut [11]:

$$
\mathrm{I}=\frac{\Sigma U+\Sigma L-\left(2 N * s_{\min }\right)}{2 N\left(s_{\max }-s_{\min }\right)}
$$


ISSN 2252-9063

Kumpulan Artikel Mahasiswa Pendidikan Teknik Informatika

(KARMAPATI)

Keterangan :

$\Sigma \mathrm{U}=$ Total skor kelompok atas

$\Sigma \mathrm{L}=$ Total skor kelompok bawah

$\Sigma s_{\text {min }}=$ Skor miimum butir

$\Sigma s_{\max }=$ Skor maksimal butir

$\mathrm{N}=$ Banyak peserta tes

Adapun pembagian tingkat kesukaran menurut Witherington sebagai berikut :

Tabel 4. Rentangan Tingkat Kesukaran Butir Soal

\begin{tabular}{|c|c|}
\hline Rentangan & Tingkat Kesukaran \\
\hline $0,00 \leq \mathrm{IKB} \leq 0,24$ & Sukar \\
\hline $0,25 \leq \mathrm{IKB} \leq 0,74$ & Sedang \\
\hline $0,75 \leq \mathrm{IKB} \leq 1,00$ & Mudah \\
\hline
\end{tabular}

\section{4) Uji Indek Daya Beda}

Daya beda butir adalah kemampuan suatu butir soal yang dapat membedakan antar siswa yang telah menguasai materi yang ditanyakan dan siswa yang belum menguasai materi yang ditanyakan. Jika tes atau soal mengukur hal yang sama, dapat diharapkan bahwa setiap peserta tes mampu menjawab soal dengan benar dan yang tidak mampu akan menjawab salah. Indeks daya beda tes hasil belajar sesuai dihitung dengan menggunakan rumus dibawah ini [11]:

$$
\mathrm{d}=\frac{(n-1)\left(\mathrm{N}^{2}-\Sigma \mathrm{f}_{\mathrm{i}}^{2}\right)}{n N^{2}}
$$

Keterangan :

$\mathrm{d}=$ Indeks daya beda

$\mathrm{N}=$ Banyak peserta tes

$\mathrm{f}_{1}=$ Frekuensi pada tiap-tiap skor

$\mathrm{n}=$ Banyak nutir

Kriteria yang digunakan dalam menentukan daya pembeda tes adalah sesuai Tabel 5.

Tabel 5. Kriteria Uji Daya Beda Butir

\begin{tabular}{|c|c|}
\hline Indeks Daya Beda & Keterangan \\
\hline $\mathrm{D} \leq 0,00$ & Sangat Jelek \\
\hline $0,00 \leq \mathrm{D} \leq 0,20$ & Jelek \\
\hline $0,20 \leq \mathrm{D} \leq 0,40$ & Cukup \\
\hline $0,40 \leq \mathrm{D} \leq 0,70$ & Baik \\
\hline $0,70 \leq \mathrm{D} \leq 1,00$ & Sangat Baik \\
\hline
\end{tabular}

\section{F. Teknik Analisis Data}

Teknik analisis data dalam penelitian ini menggunakan analisis statistik deskriptif dan statistik inferensial (uji-t) untuk menguji hipotesis penelitian. Data yang diperoleh dalam penelitian ini adalah data kuantitatif dan kualitatif. Data tersebut diolah menggunakan analisis statistik dan analisis non statistik. Data kuantitatif akan dianalisis dengan analisis statistic deskriptif untuk mendeskripsikan data hasil belajar siswa. Kemudian data kualitatif dianalisis dengan memberi makna terhadap deskripsi data. uji prasyarat berupa uji normalitas dan uji homogenitas, serta uji hipotesis. Sebelum dianalisis dengan uji-t data diuji prasyarat terlebih dahulu.

\section{1) Teknik Analisis Deskriptif}

Analisis deskriptif dilakukan untuk mengetahui tinggi rendahnya kualitas dari hasil belajar. Metode analisis deskriptif kuantitatif adalah suatu cara pengolahan data yang dilakukan dengan cara menyusun secara sistematis dalam bentuk angkaangka persentase, mengenai suatu objek yang diteliti sehingga diperoleh kesimpulan umum. Penentuan kualitas variabelvariabel, skor rata-rata (mean) tiap-tiap variabel dikonversikan dengan menggunakan kriteria rata-rata ideal dan standar deviasi (SD) seperti pada Tabel 6.

Tabel 6. Uji Mean Ideal Dan Standar Deviasi Ideal

\begin{tabular}{|l|c|}
\hline \multicolumn{1}{|c|}{ Rentangan Skor } & Kategori \\
\hline $\mathrm{MI}+1,5 \mathrm{SDI} \leq \mathrm{X}$ & Sangat Tinggi \\
\hline $\mathrm{MI}+0,5 \mathrm{SDI} \leq \mathrm{X}<\mathrm{MI}+1,5 \mathrm{SDI}$ & Tinggi \\
\hline $\mathrm{MI}-0,5 \mathrm{SDI} \leq \mathrm{X}<\mathrm{MI}+0,5 \mathrm{SDI}$ & Sedang \\
\hline $\mathrm{MI}-1,5 \mathrm{SDI} \leq \mathrm{X}<\mathrm{MI}-0,5 \mathrm{SDI}$ & Rendah \\
\hline $\mathrm{X}<\mathrm{MI}-1,5 \mathrm{SDI}$ & Sangat Rendah \\
\hline
\end{tabular}

Sumber : [12]

Keterangan :

$\mathrm{X}=$ Kualifikasi nilai

$\mathrm{Mi}=\frac{1}{2}($ skor tertinggi ideal + skor terendah ideal $)$

Sdi $=\frac{1}{6}($ skor tertinggi ideal + skor terendah ideal $)$.

\section{2) Teknik Uji Prasyarat Analisis}

Sebelum dilakukan uji hipotesis, data yang dikumpulkan diuji prasyarat terlebih dahulu. Uji prasyarat ini dilakukan untuk membuktikan bahwa data yang dikumpulkan layak untuk dianalisis dengan statistic parametric atau tidak. Uji prasyarat yang dilakukan adalah uji normalitas dan uji homogenitas varians.

\section{a) Uji Normalitas}

Uji normalitas sebaran dilakukan untuk menyajikan bahwa sampel benar-benar berasal dari populasi yang berdistribusi 
ISSN 2252-9063

Kumpulan Artikel Mahasiswa Pendidikan Teknik Informatika

(KARMAPATI)

normal. Uji normalitas dilakukan untuk menentukan langkah pengujian dengan menggunakan pengujian statistik parametrik atau non parametrik. Hipotesis yang akan diajukan adalah :

\section{$\mathrm{H}_{0}$ : Data berdistribusi Normal \\ $\mathrm{H}_{1}$ : Data tidak berdistribusi Normal}

Uji normalitas data dilakukan dengan uji Kolmogorov-Smirnov dengan rumus seperti berikut.

$$
\mathrm{D}=\left|\mathrm{F}_{\mathrm{s}}(\mathrm{x})-\mathrm{F}_{\mathrm{t}}(\mathrm{x})\right| \max
$$

\section{Keterangan :}

$\mathrm{F}_{s}(\mathrm{x})$ : Distribusi Frekuensi kumulatif sampel

$\mathrm{F}_{\mathrm{t}}(\mathrm{x})$ : Distribusi Frekuensi kumulatif teoritis

Kriteria pengujian yang digunakan dengan sebaran angka signifikansi yang dihasilkan lebih dari 5\% dan dalam hal lain data tidak berdistribusi normal.

\section{b) Uji Homogenitas Varian}

Uji homogenitas ini dilakukan untuk mencari tingkat kehomogenan secara dua pihak yang diambil dari kelompokkelompok terpisah dari satu populasi yaitu kelompok kontrol dan kelompok eksperimen. Untuk menguji homogenitas varians untuk kedua kelompok digunakan uji F, Hipotesis yang akan diujikan adalah :

$\mathrm{H}_{0}$ : Tidak terdapat perbedaan varians antara kelompok eksperimen dan kelompok kontrol (homogen)

$\mathrm{H}_{1}$ : Terdapat perbedaan varians antara kelompok eksperimen dan kelompok kontrol (tidak homogen)

Dengan rumus uji F seperti berikut [10]

$$
F_{\text {hit }}=\frac{s_{1}{ }^{2}}{s_{2}{ }^{2}}
$$

Keterangan :

$$
\begin{array}{ll}
\mathrm{S}_{1}{ }^{2} & \text { : varian terbesar } \\
\mathrm{S}_{2}{ }^{2} & \text { : varian terkecil }
\end{array}
$$

Kriteria pengujian, jika $\mathrm{F}_{\text {hit }}<\mathrm{F} \alpha_{(\mathrm{n} 1-1, \text { n2-2) }}$ maka sampel homogen dapat melakukan pengujian dengan menggunakan rumus separated varians maupun polled varians dan jika $\mathrm{F}_{\text {hit }}>$ $\mathrm{F} \alpha_{(\mathrm{n} 1-1, \mathrm{n} 2-2)}$ maka sampel tidak homogen dapat melakukan pengujian dengan menggunakan rumus separated varians. Pengujian dilakukan pada taraf signifikan 5\% dengan derajat kebebasan untuk pembilang $\mathrm{n}_{1}-1$ dan derajat kebebasan untuk penyebut $\mathrm{n}_{2}-2$.

\section{c) Uji Hipotesis Penelitian}

Uji hipotesis digunakan untuk menguji hipotesis yang telah dilakukan pada penelitian ini, yaitu terdapat perbedaan belajar tinggi terhadap hasil belajar mata pelajaran anatomi fisiologi antara siswa yang mengikuti pembelajaran mind mapping bermediakan rumah belajar jejak bali dengan siswa yang mengikuti pembelajaran discovery learning bermediakan powerpoint pada mata pelajaran anatomi fisiologi kelas $\mathrm{X}$ jurusan keperawatan di SMK Negeri 1 Kubutambahan. Pengujian hipotesis dijabarkan menjadi hipotesis nol $\left(\mathrm{H}_{0}\right)$ melawan hipotesis alternatif $\left(\mathrm{H}_{1}\right)$. Secara statistik hipotesis tersebut dapat dirumuskan sebagai berikut :

$\mathrm{H}_{0}: \mu_{1}=\mu_{2}$ melawan $\mathrm{H}_{1}: \mu_{1}, \mu_{2}$

Artinya adalah :

$\mathrm{H}_{0}: \mu_{1}=\mu_{2}$ : Tidak terdapat perbedaan hasil belajar yang lebih tinggi antara siswa yang belajar menggunakan pembelajaran mind mapping bermediakan rumah belajar jejak bali dengan siswa yang belajar menggunakan pembelajaran discovery learning bermediakan powerpoint.

$\mathrm{H}_{1}: \mu_{1}>\mu_{2}$ : Terdapat perbedaan hasil belajar yang lebih tinggi antara siswa yang belajar menggunakan pembelajaran mind mapping bermediakan rumah belajar jejak bali dengan siswa yang belajar menggunakan pembelajaran discovery learning bermediakan powerpoint

Keterangan :

$\mu_{1}=$ Skor rata-rata hasil belajar siswa kelas eksperimen $(\mathrm{KE})$

$\mu_{2}=$ Skor rata-rata hasil belajar siswa kelas kontrol (KK)

Teknik analisis data yang digunakan untuk menguji hipotesis yaitu menganalisis perbedaan antara dua kelompok skor. Jika terbukti bahwa data yang dikumpulkan berdistribusi normal dan homogen ataupun tidak homogen, maka untuk menguji hipotesis pada penelitian ini akan digunakan uji-t dengan taraf signifikan 5\%. T-test yang digunakan adalah separated varian ataupun polled varian. Pengujian hipotesis menggunakan t-test, terdapat beberapa rumus yang digunakan rumus seperti berikut.

\section{Rumus (separated varians)}

$$
t=\frac{\overline{X_{1}}-\overline{X_{2}}}{\sqrt{\frac{s_{1}{ }^{2}}{n_{1}}+\frac{s_{2}{ }^{2}}{n_{2}}}}
$$


ISSN 2252-9063

Kumpulan Artikel Mahasiswa Pendidikan Teknik Informatika

(KARMAPATI)

Volume 8, Nomor 2, Tahun 2019

atau

Rumus (polled varians)

$$
t=\frac{\bar{X}_{1}-\bar{X}_{2}}{\sqrt{\frac{\left(n_{1}-1\right) s_{1}^{2}+\left(n_{2}-1\right) s_{2}^{2}}{n_{1}+n_{2}-2}\left(\frac{1}{n_{1}}+\frac{1}{n_{2}}\right)}}
$$

Keterangan :

$$
\begin{aligned}
& \bar{X}_{1}=\text { Nilai rata-rata skor kelompok eksperimen } \\
& \bar{X}_{2}=\text { Nilai rata-rata skor kelompok kontrol } \\
& \mathrm{n}_{1}=\text { Banyaknya kelompok eksperimen } \\
& \mathrm{n}_{2}=\text { Banyaknya kelompok kontrol } \\
& \mathrm{S}_{1}^{2}=\text { Varians kelompok eksperimen } \\
& \mathrm{S}_{2}^{2}=\text { Varians kelompok kontrol }
\end{aligned}
$$

Pedoman penggunaan rumus-rumus t-test separated varian, dan polled varian yaitu sebagai berikut :

a. Bila jumlah siswa $\mathrm{n}_{1}=\mathrm{n}_{2}$, varian homogen maka dapat digunakan rumus t-test baik untuk separated varian maupun polled varian. Untuk melihat harga $\mathrm{t}$-tabel digunakan derajat kebebasan $(\mathrm{dk})=\mathrm{n}_{1}+\mathrm{n}_{2}$ $-2$

b. Bila jumlah siswa $\mathrm{n}_{1} \neq \mathrm{n}_{2}$, varian homogen maka dapat digunakan rumus t-test dengan polled varian. Untuk melihat harga t-tabel digunakan derajat kebebasan $(\mathrm{dk})=\mathrm{n}_{1}+\mathrm{n}_{2}-2$

c. Bila jumlah siswa $\mathrm{n}_{1}=\mathrm{n}_{2}$, varian tidak homogen dapat digunakan rumus t-test dengan separated varian dan polled varian. Untuk melihat harga ttabel digunakan derajat kebebasan $(\mathrm{dk})=\mathrm{n}_{1}-1$ atau $\mathrm{n}_{2}-1$

d. Bila jumlah siswa $\mathrm{n}_{1} \neq \mathrm{n}_{2}$, varian tidak homogen untuk ini digunakan t-test dengan separated varian. Harga $t$ sebagai pengganti t-tabel dihitung dari selisih harga t-tabel dengan $\mathrm{dk}\left(\mathrm{n}_{1}-1\right)$ dan $\mathrm{dk}\left(\mathrm{n}_{2}\right.$ 1) dibagi dua, dan kemudian ditambahkan dengan harga $t$ yang terkecil.

Untuk mendapatkan hasil yang lebih akurat analisis uji-t dilakukan dengan dua cara yaitu secara manual dan dengan bantuan program SPSS 20 for Windows. Apabila cara manual untuk menghasilkan interpretasi, maka thitung tersebut harus dikomparasi dengan $\mathrm{t}_{\text {tabel }}$ dengan indikator

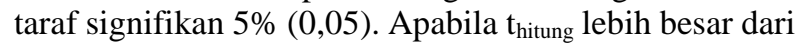
pada $t_{\text {tabel }}\left(t_{\text {hitung }}>t_{\text {tabel }}\right)$ maka terdapat perbedaan yang signifikan antara kedua variabel atau sampel. Sedangkan apabila $t_{\text {hitung }}$ lebih kecil dari pada $t_{\text {tabel }}\left(t_{\text {hitung }}<t_{\text {tabel }}\right)$ maka tidak terdapat perbedaan yang signifikan antara kedua variabel atau sampel. Sedangkan hasil interpretasi output program SPSS 20.0 for Windows dilakukan dengan melihat nilai signifikansi. Angka signifikansi lebih kecil dari 0,05 berarti $\mathrm{H}_{0}$ ditolak dan artinya terdapat perbedaan variabel bebas antar kelompok.

\section{HASIL \& PEMBAHASAN}

A. Hasil Penelitian

Berdasarkan data pengukuran hasil belajar kognitif terhadap 30 siswa kelompok eksperimen, diperoleh data distribusi frekuensi skor post-test hasil belajar kognitif kelompok eksperimen, diketahui bahwa nilai tertinggi siswa adalah 83,33 dan nilai terendah siswa adalah 68,33 dengan rentangan 15 , banyak kelas interval 6 dan panjang kelas interval adalah 3 . Rata-rata atau mean (M) hasil yang dicapai siswa pada kelas eksperimen sebesar 75,7. Kategori nilai data hasil belajar siswa kelas eksperimen dilihat pada Gambar 2.

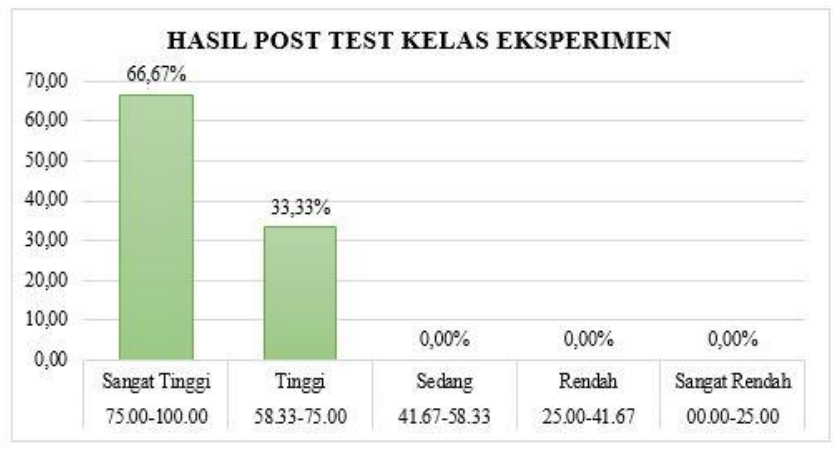

Gambar 3. Histogram Hasil Belajar Kelompok Eksperimen

Berdasarkan data pengukuran hasil belajar kognitif terhadap 29 siswa kelompok kontrol, diperoleh data distribusi frekuensi skor post-test hasil belajar kognitif kelompok kontrol, diketahui bahwa nilai tertinggi siswa adalah 61,67 dan nilai terendah siswa adalah 45,00 dengan rentangan 17, banyak kelas interval 6 dan panjang kelas interval adalah 2,917. Rata-rata atau mean (M) hasil belajar yang dicapai siswa pada kelas kontrol sebesar 53,655. Kategori skor data hasil belajar siswa kelas kontrol dilihat pada Gambar 3.

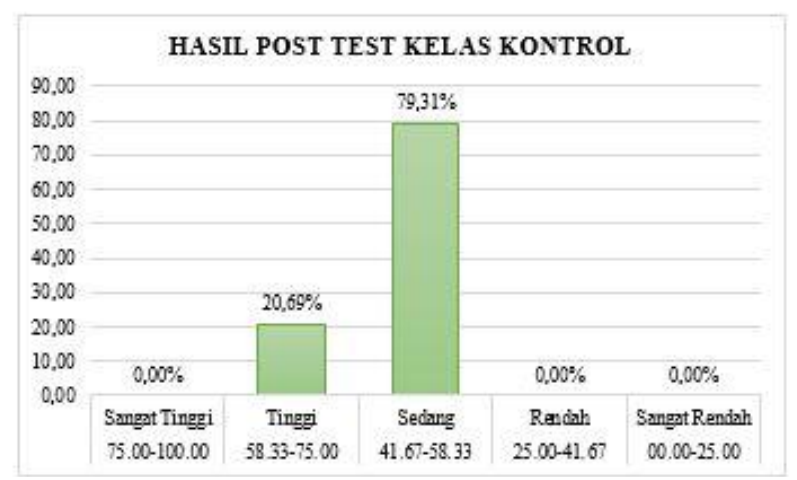

Gambar 4. Histogram Hasil Belajar Kelompok Kontrol 
ISSN 2252-9063

Kumpulan Artikel Mahasiswa Pendidikan Teknik Informatika

(KARMAPATI)

Perhitungan uji prasyarat dilakukan dalam dua buah uji yakni uji normalitas dan uji homogenitas. Berdasarkan hasil output analisis uji normalitas menunjukkan nilai KolmogrovSminov dengan probabilitas (sig) sebesar 0,200 dan nilai Shapiro Wilk dengan probabilitas (a) sebesar 0,709, oleh karena nilai probabilitas kedua nilai signifikan $>0,05$ maka ini berarti bahwa data hasil posttest kelompok eksperimen berdistribusi normal yaitu tidak terdapat perbedaan frekuensi sebaran data kelompok eksperimen. Berdasarkan hasil output analisis uji normalitas kelompok kontrol menunjukkan nilai KolmogrovSminov dengan probabilitas (sig) sebesar 0,180 dan nilai Shapiro Wilk dengan probabilitas (a) sebesar 0,153, oleh karena nilai probabilitas kedua nilai signifikan $>0,05$ maka ini berarti bahwa data hasil posttest kelompok kontrol berdistribusi normal yaitu tidak terdapat perbedaan frekuensi sebaran data kelompok kontrol.

Perhitungan selanjutnya adalah uji homogenitas menggunakan SPSS 20.0. Berdasarkan hasil output analisis menunjukkan nilai signifikan sebesar 0,256 , oleh karena nilai signifikan > 0,05 maka data hasil belajar kelompok eksperimen dan kelompok kontrol dikatakan homogen yaitu tidak terdapat perbedaan varians antara kelompok eksperimen dan kelompok kontrol.

Karena data kelas eksperimen dan kelas kontrol telah berdistribusi normal dan data homogen maka dilanjutkan dengan melakukan uji hipotesis dengan menggunakan uji-t. Uji-t dapat dihitung dengan menggunakan Ms. Excel 2010 dan SPSS 20.0. Uji-t dihitung menggunakan rumus Polled Varians memperoleh thitung sebesar 20,316.

Nilai $t_{\text {tabel }}$ dengan db 59-2 = 57 adalah sebesar 2,0024. Berdasarkan perhitungan uji-t diperoleh $t_{\text {hitung }}>t_{\text {tabel }}$ yaitu 20,316> 2,00246 maka $\mathrm{H}_{0}$ ditolak, berarti $\mathrm{H}_{1}$ diterima. Berdasarkan hal ini dapat diartikan bahwa tidak terdapat hasil belajar yang lebih tinggi antar siswa yang belajar menggunakan pembelajaran mind mapping bermediakan rumah belajar jejak bali dengan siswa belajar menggunakan pembelajaran discovery learning bermediakan powepoint dinyatakan ditolak, dengan demikian $\mathrm{H}_{1}$ yang menyatakan terdapat perbedaan hasil belajar yang lebih tinggi antara siswa yang belajar menggunakan pembelajaran mind mapping bermediakan rumah belajar jejak bali dengan siswa belajar menggunakan pembelajaran discovery learning bermediakan powerpoint. Ujit juga dihitung dengan menggunakan SPSS 20.0 dengan hasil sebagai berikut:

Tabel 7. Hasil Uji Hipotesis Dengan SPSS

\begin{tabular}{|c|c|c|c|c|}
\hline \multicolumn{2}{|c|}{ Equal variance } & \multicolumn{3}{c|}{ t-test for Equality of Means } \\
\cline { 3 - 5 } \multicolumn{2}{|c|}{} & $\begin{array}{c}\text { Sig. } \\
\text { (2tailed) }\end{array}$ & Mean & Std \\
\hline \multirow{2}{*}{ Nilai } & $\begin{array}{c}\text { Equal variance } \\
\text { assumed }\end{array}$ & .000 & 22.160 & 1.08756 \\
\cline { 2 - 5 } & $\begin{array}{c}\text { Equal variance } \\
\text { not assumed }\end{array}$ & .000 & 22.160 & 1.08756 \\
\hline
\end{tabular}

Berdasarkan hasil perhitungan post test kelompok eksperimen dan kelompok control dengan menggunakan SPSS 20.0 dari output analisis menunjukan nilai sig. adalah 0.000 . Oleh karena nilai probabilitas signifikan < 0,05 maka H0 ditolak atau $\mathrm{H} 1$ diterima. Sehingga dapat dikatakan kelas control dan kelas eksperimen memiliki rata-rata yang berbeda atau tidak setara.

Data dari hasil respon siswa terhadap penggunaan pembelajaran mind mapping bermediakan rumah belajar jejak bali pada mata pelajaran Anatomi Fisiologi terhadap 30 siswa kelompok eksperimen memiliki rata-rata 112,47 dan diketahui bahwa respon siswa terhadap penggunaan pembelajaran mind

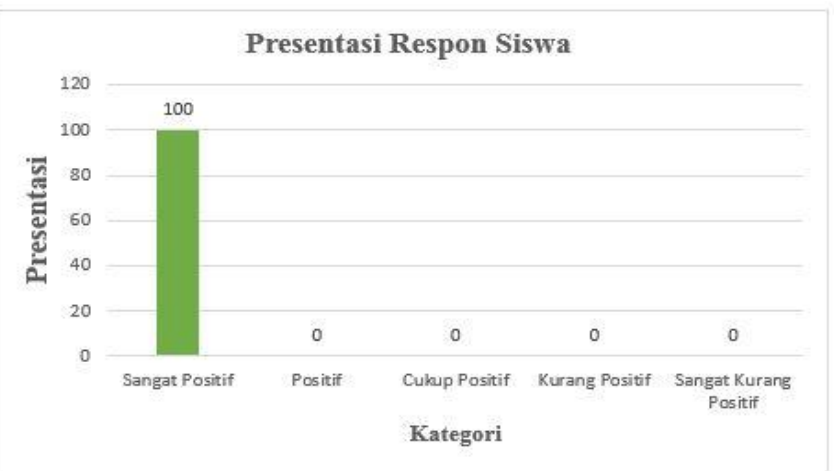

Gambar 5. Histogram Respon Siswa

mapping bermediakan rumah belajar jejak bali pada mata pelajaran Anatomi Fisiologi sebanyak 100\% berkategori sangat positif, sedangkan berkategori positif, berkategori positif serta sangat kurang positif memperoleh nilai sebesar 0\%. Hasil respon siswa untuk lebih jelas dapat dilihat pada Gambar 4.

\section{B. Pembahasan}

Hasil penelitian meliputi analisis deskriptif dan analisis statistic yang mengungkap pengaruh variable bebas terhadap variable terikat. Variabel bebas dalam penelitian ini adalah pembelajaran mind mapping bermediakan rumah belajar jejak bali sedangkan variable terikat dalam penelitian ini adalah hasil belajar mata pelajaran anatomi fisiologi.

Sebelum menentukan anggota sampel, terlebih dahulu menentukan anggota populasi. Anggota populasi dalam penelitian ini adalah siswa kelas $\mathrm{X}$ jurusan keperawatan yang terdiri dari kelas X KP 1, X KP 2 , X KP 3 dan X KP 4 di SMK Negeri 1 Kubutambahan. Jumlah anggota populasi yang telah ditentukan dalam penelitian ini adalah 117 siswa. Dalam penelitian ini, pemilihan sampel yang digunakan sebagai kelas eksperimen dan kelas control dilakukan uji kesetaraan terlebih dahulu untuk meyakinkan bahwa kelas benar-benar dalam keadaan setara dari segi kemampuan akademisnya. Setara dalam artian pengelompokan siswa ke dalam kelas-kelas tersebut disebar secara merata antara siswa yang memiliki 


\section{ISSN 2252-9063 \\ Kumpulan Artikel Mahasiswa Pendidikan Teknik Informatika \\ (KARMAPATI)

kemampuan tinggi, sedang, dan rendah. Uji kesetaraan dilakukan terhadap empat kelas dengan menggunakan nilai Ulangan Tengah Semester tahun pelajaran 2018/2019. Hasil tes ulangan tengah semester yang dianalisis adalah hasil murni dalam artian nilai belum mendapatkan perlakuan remedial.

Setelah mendapatkan pasangan kelas yang setara sebanyak empat kelas, selanjutnya dilakukan teknik Simple Random Sampling untuk menentukan kelas yang akan digunakan sebagai sampel. Hasil pengundian didapatkan bahwa kelas $\mathrm{X}$ KP 1 sebagai kelas eksperimen dan X KP 3 adalah kelas kontrol. Kelas eksperimen adalah kelompok yang diberi perlakuan yaitu dengan pembelajaran mind mapping bermediakan rumah belajar jejak bali, kelas kontrol adalah kelompok siswa yang belajar dengan pembelajaran discovery learning bermediakan powerpoint. Penelitian ini dilaksanakan dalam 5 kali pertemuan, yang terdiri dari 4 kali proses pembelajaran dan 1 kali pertemuan untuk post-test yang dilakukan pada kelas eksperimen dan control.

Setelah diberikan perlakuan, selanjutnya diberikan tes akhir pada kelas eksperimen dan kelas control dengan tujuan untuk mengetahui hasil belajar siswa setelah diberi perlakuan. Analisis dari hasil penelitian didapat bahwa rata-rata post test hasil belajar pada kelompok eksperimen adalah 73,3 sedangkan rata-rata post test hasil belajar untuk kelompok control sebesar 53,33. Dengan demikian ,rata-rata post test hasil belajar pada kelompok eksperimen lebih besar dibandingkan kelompok control. Untuk perhitungan normalitas, homogenitas, dan uji t menggunakan Microsoft excel dan SPSS hasilnya tidak jauh berbeda, dimana kedua kelompok baik kelompok eksperimen dan kelompok control memiliki data yang normal dan homogen.

Perhitungan Uji hipotesis dengan uji t menggunakan Microsoft Excel 2010 dengan taraf signifikansi 5\% dan derajat kebebasan 57 diperoleh $t_{\text {hitung }}=20,316$ dan $t_{\text {tabel }}=2,0024$. Karena $t_{\text {hitung }}>t_{\text {tabel }}$ maka $\mathrm{H}_{0}$ ditolak dan $\mathrm{H}_{1}$ diterima. Sedangkan analisis uji t dengan SPSS 20.0 mendapat hasil thitung sebesar 20,377 dengan taraf signifikan 5\%. Oleh karena itu hasil probabilitas signifikan $<0,05$ maka $\mathrm{H}_{0}$ ditolak dan $\mathrm{H}_{1}$ diterima . Berarti kedua temuan tersebut menunjukkan bahwa terdapat hasil belajar yang lebih tinggi antara siswa yang belajar dengan menggunakan pembelajaran mind mapping bermediakan rumah belajar jejak bali dengan siswa yang belajar menggunakan pembelajaran discovery learning bermediakan powerpoint pada mata pelajaran anatomi fisiologi di SMK Negeri 1 Kubutambahan.

Berdasarkan analisis hasil penelitian dan pembahasan menunjukkan bahwa terdapat perbedaan hasil belajar siswa pada kelas eksperimen menggunakan pembelajaran mind mapping bermediakan rumah belajar jejak bali. Perbedaan ini disebabkan oleh adanya pembelajaran mind mapping bermediakan rumah belajar jejak bali yang membantu siswa dalam memahami materi yang diajarkan oleh guru didalam proses penyampaian materi dikelas, dengan adanya pembelajaran mind mapping ini siswa lebih kreatif, aktif didalam proses merespon pertanyaan dari guru maupun dari siswa lain didalam proses pembelajaran belangsung. Hal lainnya ketika diberikan perlakuan berupa pembelajaran mind mapping siswa yang awalnya bosan mengikuti pembelajaran dikelas setelah diberikan perlakuan berupa pembelajaran mind mapping siswa lebih senang dikarenakan hal ini terlihat jelas ketika siswa diajak bersama-sama menyelesaikan masalah dengan berdiskusi kelompok dan menyelesaikan permasalahan yang diberikan oleh guru berupa gambar ataupun simbol yang membuat siswa kreatif, aktif didalam proses membuat gambaran tugas yang diberikan oleh guru. Sedangkan media pembelajaran e-learning rumah belajar jejak bali yaitu media pembelajaran yang memberikan kesempatan kepada siswa untuk aktif didalam mencari bahan materi ajar sendiri tanpa selalu berpusat lagi kepada guru didalam penyampaian materi dikelas, sehingga siswa mandiri dan aktif turut serta didalam proses pembelajaran.

Hasil analisis respon terhadap penggunaan pembelajaran mind mapping bermediakan rumah belajar jejak bali berada pada presentase $100 \%$ kategori sangat positif. Keadaan seperti ini akan menciptakan suasana belajar yang efektif agar bisa meningkatkan hasil belajar siswa yang lebih tinggi. Jadi, dengan diperolehnya respon siswa yang sangat positif terhadap penerapan pembelajaran mind mapping bermediakan rumah belajar jejak bali pada mata pelajaran anatomi fisiologi di dalam kelas dapat mengindikasikan bahwa pembelajaran mind mapping bermediakan rumah belajar jejak bali ini dapat diterima dengan baik oleh siswa.

Dalam penelitian ini adapun kendala-kendala yang dihadapi peneliti saat menerapkan pembelajaran mind mapping bermediakan rumah belajar jejak bali adalah siswa belum terbiasa dalam mengimplementasikan e-learning rumah belajar jejak bali, sehingga saat guru meminta siswa untuk menggunakan e-learning rumah belajar jejak bali terdapat kendala yang masih dialami siswa seperti lupa dengan username dan password yang sudah didaftarkan ke sistem media pembelajaran rumah belajar jejak bali, dan belum memahami urutan langkah pembelajaran yang harus diperhatikan pada e-learning rumah belajar jejak bali. Solusi yang diberikan terhadap kendala ini adalah mahasiswa selaku peneliti selalu mengingatkan siswa agar menyimpan akses login yang mereka gunakan pada Smartphone/Android ataupun laptop mereka masing-masing agar nanti ketika ingin login kembali hanya tinggal memilih username yang sudah tersimpan sebelumnya. Kemudian berkoordinasi dengan guru tentang tahapan penggunaan e-learning rumah belajar jejak bali agar sesuai dengan model pembelajaran yang digunakan. Kedua, kendala yang muncul disaat proses penelitian berlangsung yaitu jadwal proses pembelajaran dikelas khususnya kelas kontrol banyak mengalami benturan dengan jadwal kegiatan sekolah. Solusi yang diberikan terhadap kendalan ini adalah peneliti menyarankan kepada peneliti lain yang akan melakukan 
ISSN 2252-9063

Kumpulan Artikel Mahasiswa Pendidikan Teknik Informatika

(KARMAPATI)

penelitian sejenis bisa mengonsultasikan/menanyakan kepada staff tata usaha sekolah serangkaian jadwal kegiatan disekolah, agar disaat proses penelitian berlangsung berjalan dengan baik dan tidak ada lagi perubahan jadwal yang sudah disepakati oleh guru pengajar sebelumnya. Berdasarkan pertimbanganpertimbangan teoritik dan operasional, maka implikasi dari penelitian ini jika dilihat dari teori belajar konstruktivisme adalah proses belajar dan pembelajaran di kelas. Siswa harus dapat mengaplikasikan ide-ide mereka sendiri, siswa harus mengkonstruksikan pengetahuan dibenak mereka sendiri sehingga hasil belajar dicapai dengan lebih baik. Bedasarkan hal ini pembelajaran dan media pembelajaran yang dapat digunakan untuk mencapai hasil belajar dengan lebih baik adalah pembelajaran mind mapping bermediakan rumah belajar jejak bali.

\section{SIMPULAN}

Berdasarkan hasil penelitian dan pembahasan yang sudah dipaparkan, maka dapat dikemukakan beberapa simpulan dalam penelitian ini. Adapun simpulan yang akan dikemukakan dalam penelitian ini adalah sebagai berikut.

1) Terdapat hasil belajar yang lebih tinggi antara siswa yang belajar menggunakan pembelajaran mind mapping bermediakan rumah belajar jejak bali dikelas $\mathrm{X}$ keperawatan 1 sebagai kelas eksperimen dengan siswa belajar menggunakan pembelajaran discovery learning bermediakan powerpoint dikelas X keperawatan 3 sebagai kelas kontrol pada mata pelajaran anatomi fisiologi di SMK Negeri 1 Kubutambahan. Dilihat dari rata-rata hasil belajar kelompok eksperimen dengan penerapan pembelajaran mind mapping bermediakan rumah belajar jejak bali memperoleh rata-rata 75,66 sedangkan rata-rata untuk kelas kontrol sebesar 53,50. Bedasarkan rata-rata hasil belajar tersebut maka dapat disimpulkan bahwa hasil belajar lebih tinggi terdapat pada siswa yang menggunakan pembelajaran mind mapping bermediakan rumah belajar jejak bali.

2) Hasil dari analisis respon siswa dalam penerapan pembelajaran mind mapping bermediakan rumah belajar jejak bali pada mata pelajaran anatomi fisiologi memperoleh rata-rata skor respon siswa sebesar 112,47 jumlah rata-rata tersebut termasuk dalam kategori sangat positif yang artinya dapat disimpulkan bahwa dengan pembelajaran mind mapping bermediakan dengan pembelajaran e-learning rumah belajar jejak bali membuat menarik minat siswa untuk belajar.

Berdasarkan hasil penelitian dapat diajukan beberapa saran guna meningkatkan kualitas pembelajaran Anatomi Fisiologi yang diantaranya :
1) Hasil penelitian ini menunjukan bahwa siswa yang belajar dengan menggunakan pembelajaran mind mapping bermediakan rumah belajar jejak bali memperoleh hasil yang lebih baik daripada siswa yang menggunakan pembelajaran discovery learning bermediakan powerpoint. Oleh karena itu, penulis menyarakan kepada guru pengajar dan pihak sekolah terkait agar menimbangkan kembali model pembelajaran dan media pembelajaran yang digunakan agar tidak lagi model dan media pembelajaran terus menerus digunakan disetiap tahunnya dan

2) Peneliti ini dilakukan dengan berbagai keterbatasan, terutama kondisi kelas, materi, dan media yang digunakan. Disarankan untuk peneliti yang tertarik dapat melakukan peneliti sejenis dengan model pembelajaran mind mapping bermediakan rumah belajar jejak sebaiknya menggunakan aplikasi mind mapping pada mata pelajaran yang berbeda dan jenjang yang berbeda.

\section{REFERENCES}

[1] K. Agustini and D. S. Wahyuni, "Pengaruh Penggunaan Simulasi Binary Tree Bebasis CAI Terhadap Motivasi Dan Hasil Belajar Matematika Diskrit Mahasiswa Jurusan PTI Undiksha," J. Pendidik. Indones., vol. 2, no. 1, 2013.

[2] N. Hidayati, "Penggunaan Mind Mapping Dalam Mata Kuliah Anatomi Fisiologi Manusia Sebagai Intergrasi Berbagai Konsep Untuk Meningkatkan Hasil Belajar Mahasiswa TA 2014/2015," vol. 2, no. 2, pp. 58-62, 2015.

[3] H. W. Latipah and Adman, "Penerapan Model Pembelajaran Mind Mapping Untuk Meningkatkan Hasil Belajar Peserta Didik ( Studi Kuasi Eksperimen Pada Kompetensi Dasar Program Keahlian Administrasi Perkantoran di SMKN 3 Bandung )," Pendidik. Manaj. Perkantoran, vol. 1, pp. 125-137, 2018.

[4] Depdiknas, Undang-Undang Republik Indonesia Nomor 20 Tahun 2003. Bandung: Fokusmedia, 2006.

[5] I. W. Suwatra, I. K. Pudjawan, I. D. K. Tastra, and I. K. Sudarma, Modul Belajar dan Pembelajaran. Singaraja: Universitas Pendidikan Ganesha, 2007.

[6] N. N. Parwati, I. P. P. Suryawan, and R. A. Apsari, Belajar dan Pembelajaran. Depok: PT Raja Grafindo Persada, 2018.

[7] A. Shoimin, 68 Model Pembelajaran Inovatif Dalam Kurikulum 2013. Yogyakarta: Ar-Ruzz Media, 2017.

[8] N. Suryani and L. Agung, Strategi Belajar Mengajar. Yogyakarta: Ombak Dua, 2012.

[9] G. Aditra Pradnyana, I. M. Ardwi Pradnyana, and I. G. 
ISSN 2252-9063

Kumpulan Artikel Mahasiswa Pendidikan Teknik Informatika

(KARMAPATI)

Partha Sindhu, "Pelatihan Penggunaan E-learning Berbasis Media Sosial Edmodo Bagi Guru SMA Di Kecamatan Buleleng," Semin. Nas. Pengabdi. Kpd. Masy., p. 12, 2016.

[10] Sugiyono, Metode Penelitian Kuantitatif Kualitatif dan $R \& D$. Bandung: Alfabeta, 2009.

[11] I. M. Candiasa, Pengujian Instrumen Penelitian Disertai Aplikasi Iteman dan Bigsteps. Singaraja: Unit Penerbitan Undiksha., 2011.

[12] N. Sugihartini, Strategi Pembelajaran Pendekatan Pembelajaran Inovatif Disertai Dengan Aplikasi Pembelajaran Bidang Teknologi Informasi dan Komunikasi (TIK). Singaraja: Undiksha Press, 2016. 